\title{
SCIENTIFIC REPRTS \\ OPEN Author Correction: The effects of aquarium culture on coral oocyte ultrastructure
}

\section{Chiahsin Lin ${ }^{1,2}$, Jian-Ming Zhuo ${ }^{2}$, Gabriella Chong ${ }^{2}$, Li-Hsueh Wang ${ }^{1,2}$, Pei-Jie Meng ${ }^{1,2}$ \& Sujune Tsai ${ }^{3,4}$}

Correction to: Scientific Reports https://doi.org/10.1038/s41598-018-33341-x, published online 11 October 2018

This Article contains an error in the legend of Figure 2.

“TEM images of Oxypora lacera mitochondria ( $\mathrm{m}$ ) and Golgi bodies (denoted by arrow) from wild (a) and cultured $(\mathbf{b})$ oocytes. $\mathrm{yb}=$ yolk body. $\mathrm{lg}=$ lipid granule. The scale represents 1 um."

should read:

"TEM images of Oxypora lacera mitochondria (m) and Golgi bodies (denoted by arrow) from wild oocytes (a and b). $\mathrm{yb}=$ yolk body. $\mathrm{lg}=$ lipid granule. The scale represents $1 \mathrm{um} . "$

In addition, this Article contains an error in the Discussions section.

"Herein we found that wild and cultured coral oocytes differed in their ultrastructure and physiology; notably, wild coral oocytes had thicker microvillus layers, and this may be related to the presumably higher potential for heterotrophy in situ."

should read:

"Herein we found that wild and cultured coral oocytes differed in their ultrastructure and physiology; notably, wild coral oocytes had thinner microvillus layers, and this may be related to the presumably higher potential for heterotrophy in situ."

(i) Open Access This article is licensed under a Creative Commons Attribution 4.0 International License, which permits use, sharing, adaptation, distribution and reproduction in any medium or format, as long as you give appropriate credit to the original author(s) and the source, provide a link to the Creative Commons license, and indicate if changes were made. The images or other third party material in this article are included in the article's Creative Commons license, unless indicated otherwise in a credit line to the material. If material is not included in the article's Creative Commons license and your intended use is not permitted by statutory regulation or exceeds the permitted use, you will need to obtain permission directly from the copyright holder. To view a copy of this license, visit http://creativecommons.org/licenses/by/4.0/.

(C) The Author(s) 2019

${ }^{1}$ National museum of Marine Biology \& Aquarium, 2 Houwan Road, Checheng, Pingtung, 944, Taiwan. ${ }^{2}$ Institute of Marine Biology, National Dong Hwa University, 2 Houwan Road, Checheng, Pingtung, 944, Taiwan. ${ }^{3}$ Department of Biotechnology, Mingdao University, 369 Wen-Hua Road, Peetow, ChangHua, 52345, Taiwan. ${ }^{4}$ Department of Post Modern Agriculture, Mingdao University, 369 Wen-Hua Road, Peetow, Chang Hua, 52345, Taiwan. Correspondence and requests for materials should be addressed to C.L. (email: chiahsin@nmmba.gov.tw) or S.T. (email: stsai@mdu. edu.tw) 